\title{
STRATEGIES IN OPTIMIZING THE OUTPUT OF FINANCIAL REPORTING: PROJECT FOR A NATIONAL PERSPECTIVE
}

\author{
Dumitru Matis ${ }^{1}$ \\ Carmen Giorgiana Bonaci ${ }^{2}$ \\ Razvan V. Mustata ${ }^{3}$
}

\begin{abstract}
Our paper presents the scientific demarche that we are developing through a current accounting research project. Prior to its implementation, the final steps of the project are being presented for discussion and debate. Aiming at developing a functional model for optimizing the national strategy regarding financial reporting, we first make a brief introduction to accounting systems and their main traits and evolution. Accounting information and its disclosure by entities is then discussed through the review of literature. The research methodology part describes the final steps of the project and the manner in which we plan for their implementation. The final part of the paper concludes on the contribution of our project.
\end{abstract}

Key words: Financial reporting, accounting systems, accounting information, fair value, historical cost

JEL codes: $M 40, M 41$

\section{Introductory thoughts on accounting systems}

In order to reach those accounting essentials that aim at reflecting the result of following principles, but unfortunately often ends up applying rules, we must first appropriately conceptualize what represents the objective of our analysis. The distinction between accounting regulatory bodies' approach that would be rules-based or principle-based oriented, distinction that once seemed to be eternal nowadays seems to be fading away towards a mixed solution imposed through current realities. Still the question remains which of their characteristics would better serve the declared objectives of accounting? Of course establishing the later also involves clarifications concerning the users of accounting information and their hierarchy. Still, we consider a discussion on rules-based versus principle-based accounting to be useful as introduction to our research demarche that aims the optimization of financial reporting.

Rules assume the existence of precise criteria, impose certain limits, examples, scope restrictions, exemptions, and implementation guidance (Nelson, 2003, p. 91), while principles assume the understanding of some fundamentals that are afterwards used in interpreting economic transactions and events (Carmona and Trombetta, 2008, p. 456). As a consequence, principlebased accounting systems should issue general accounting standards and, unlike rules-based accounting systems, should not standardize each debatable aspect that raises questions.

The advantage of principle-based accounting systems, such as IAS/IFRS, emanates precisely from this internal flexibility of standards being issued that makes it possible for countries with diverse accounting traditions and different institutional backgrounds to apply it (Carmona and Trombetta, 2008, p. 455). The American accounting standards used to represent an

\footnotetext{
${ }^{1}$ Babes-Bolyai University, Faculty of Economics and Business Administration, 58-60 Teodor Mihali Street, FSEGA Campus, 400591 Cluj-Napoca Romania, dumitru.matis@econ.ubbcluj.ro

${ }^{2}$ Babes-Bolyai University, Faculty of Economics and Business Administration, 58-60 Teodor Mihali Street, FSEGA Campus, 400591 Cluj-Napoca Romania, carmen.bonaci@econ.ubbcluj.ro

${ }^{3}$ Babes-Bolyai University, Faculty of Economics and Business Administration, 58-60 Teodor Mihali Street, FSEGA

Campus, 400591 Cluj-Napoca Romania, razvan.mustata@econ.ubbcluj.ro
} 
example of rules-based accounting system ${ }^{4}$. We say used to because history, especially after the bankruptcies ending the $20^{\text {th }}$ century and beginning the $21^{\text {st }}$ in the US, documented FASB's intense preoccupation on the opportunity of reorienting their accounting system towards principles.

As Schipper (2003) and Nelson (2003) pointed out, when it comes to financial reporting, rules play an important role in ensuring the clarity and comparability of information being provided, but in the same time reality showed us how some rules within current accounting standards have been born precisely due to a lack of necessary principles or guided by unfitted principles (Nobes, 2005).

Establishing the right principles in certain areas, such as accounting for financial instruments, is not an easy task at all, the economic essence often being difficult to extract from the web of financial engineering that are developed by finance experts. Moreover, we believe that when it comes to financial instruments it is too much to consider that we are dealing with a principle-based accounting system, even if we are considering standards being issued by IASB (International Accounting Standards Board). While regulation being issued by the FASB are scattered within a significant number of SFASs (Statement of Financial Accounting Standards), the IASB doesn't stay far behind, despite its declared principle-based approach, having issued four standards ${ }^{5}$ in the particular area of financial instruments, not to mention their repeated amending as a response to different debatable aspects that were raised in practice.

What we must also remember is that before year 2001, IAS/IFRS were not seen by FASB as being attractive enough to offer their support. It was the extreme period of instability for financial reporting that came to light in 2001-2001 that made the FASB give a chance and look at the role of standards being issued by IASB in an American context (Bhimani, 2008, p. 444).

Therefore considering transactions' changing, differentiated nature and context, everything taking place at a global level, the ability to apply a healthy professional judgment in reflecting an entity's financial performance and position, rather than thinking about applying some predefined rules, becomes a must for any accountant, researcher or practitioner. Moreover, why wouldn't we apply Darwin's theory, stating that those species that are more receptive to change have more chances to survival, within an accounting setting? An accounting system that allows flexibility offers the chance of adaptation to change, therefore not requiring the introduction of a new rule with each change that comes up in practice.

On the other hand, when we say flexibility and professional judgment we must implicitly consider the possibility of manipulating accounting information. Using these opportunities in less ethical purposes, which we must admit are always a characteristic of the human behaviour, for sure had a say in orienting accounting systems towards rules that aim at restricting these possibilities.

We will furthermore focus our discussion on the role of accounting information, considering the fact that accounting systems should be designed in accordance to their objectives.

\section{Accounting information: literature in brief review}

The dimensions being reached by capital market activity in relation to the corresponding economy make us wonder whether unleashing these free markets din not promote finances from servant to master of the economy and even of the society (Stiglitz, 2010). The current financial

\footnotetext{
${ }^{4}$ Although all accounting standards being issued by the FASB (Financial Accounting Standards Board) are mostly based on a conceptual framework, these are completed through extremely detailed interpretations and implementation guidance (Alexander and Jermakowicz, 2006). We consider that this focus on detailed rules has the ability to induce accounting solutions that rather follow the letter of the law than its essence. The former SEC (Securities and Exchange Commission) president, Harvey Pitt considered that rules-based accounting standards determined the development of some financial engineering techniques that were created for accounting purposes and not due to economic objectives (Pitt, 2002).

${ }^{5}$ IAS 32, IAS 39, IFRS 7 and IFRS 9.
} 
crisis proved us once again how failures of the financial system impose costs to those that are not directly involved in risk taking. Another aspect that was emphasized through the current developments is that the process of providing accounting and financial information is not working as expected.

A series of subjects in the area of corporate governance are getting the interest in applied research, the process of elaborating regulations representing the main variable that should be considered, entities and their management acting in accordance to a series of rules from different sources (Dragomir, 2009). Promoting corporate governance practices and a corresponding framework, that would be able to improve the output of financial reporting would be beneficial for the good functioning of capital markets and of the completely financial system.

Representing a determinant factor in allocating resources, accounting and financial information is difficult from at least two points of view: managers are more informed than investors, while the credibility of information being provided to investors is often limited. In order to resolve the "lemons problem" it is necessary to identify and apply some strategies such as optimal contracts between managers and investors that stimulate the disclosure of private information, or even the imposing of such disclosures through regulations. Trade literature offers a series of theories with regard to disclosure of information, these being elaborated and discussed for some time now:

- The agency theory referring to the agency between shareholders and managers (Jensen and Meckling, 1976) and between creditors and managers (Jensen and Meckling, 1976; Watts, 1977);

- The theory of political costs, Watts and Zimmerman (1986) documenting that large profitable companies tend to present more voluntary disclosure;

- The signalling theory, Hughes (1986) claiming that managers could use financial reporting in order to suggest their own intentions and expectations;

- The need for capital theory, Choi (1973) documenting the relationship between the level of information being provided and the cost of capital.

Empirical studies have tried to explain the process of presenting financial information through a function whose variables include internal factors that refer to the entity and external factors that refer to the entity's environment as follows: internal factors - Akhtaruddin (2005), Ali et al. (2004), Eng and Mak (2003), Watson et al. (2002), Jaggi (2000), Raffournier (1995), Gray et al. (1995), Wallace and Naser (1995), Cook (1993 and 1989); and external factors Akhtaruddin (2005), Williams (2004), Haniffa and Cooke (2002), Chen and Jaggi (2000), Hussein (1996).

Going back to our analysis on accounting systems, the purpose would be to distinguish which accounting system would lead to better disclosure of information.

\section{Research methodology related aspects}

Our research demarche proposes the development of a detailed analysis of the two well known accounting models (the historical cost model and the fair value model) in order to identify how their components could be used in optimizing the output of financial reporting. In other words by combining a model that focuses on the past with one that focuses on the future we aim at finding the best for the present. While the concept of fair value is highly disputed through critics mainly coming from practitioners referring to its applicability, especially during such difficult times within capital markets as the current ones, historical cost still has its supporters based on its advantages offered through the simplicity of application and involved rules (Butler, 2009).

In order to create value, a company must generate and maintain decisive and long lasting competitive advantages that allow it to put its assets into good use, exceeding the cost of its capital (Rérolle, 2008). In a global economy, that involves intangibles, competitive advantages 
can be difficult to recognize (Rérolle, 1998). Economic benefits and costs of an alliance or temporary understanding with a business partner or even a competitor cannot be clearly identified. Uncertainty towards the origin and beneficiaries of future cash flows is determined by the intangibility of some assets and of the offer itself (Davis and Meyer, 1998).

Some current reactions make us think about the past, the Enron collapse inevitably coming to our thoughts. At that time, the new fair value accounting paradigm was progressively incorporated into the framework of GAAP (Generally Accepted Accounting Principles) to serve along with the well-established historical-cost accounting, but, as today, the Enron debacle involved misuses of both paradigms (Bonaci et al., 2010). Then was also an opportunity to argue against "mark-to-model" valuation, and even more to suggest the time of fair value accounting had not yet come (Barlev and Haddad, 2004).

As the title of our paper suggests, our research demarche plans on focusing on a national perspective in order to develop a functional model for optimizing the national strategy regarding financial reporting. At the level of accounting regulation, the global capital market fezability theory as developed by Bonaci et al (2010) will be used. By using formal harmonization and material harmonization, we intend to document the fact that a series of steps have already been made in the direction of implementing the international accounting referential within accounting practice of Romanian entities. What we actually intend to exploit is the connection between the area of accounting regulation and that of accounting practices by considering all links that can be logically derived. On one hand we have classical links such as formal harmonization, measuring the compatibility of accounting regulations and therefore linking different accounting referential, and material harmonization, measuring practices' compatibility to accounting regulation and therefore linking regulation to practice. On the other hand we consider that an indirect link can be derived, showing us that while certain entities apply a certain accounting referential, they might also be applying another referential through those foresights that are found within both considered sets of accounting regulations.

\section{Final remarks and premises for conclusions}

Our project aims at finding ways for improving financial reporting and stimulating accounting disclosure that has the ability of keeping pace with changes taking place in real economies, while also helping fortify the watching of the financial system.

The dynamic of changes taking place in value management imposed us to rethink the manner in which we approach the image of performance. Nevertheless, we can not neglect the role of accounting aspects, and more precisely the impact accounting standards and their implementation have on management's behaviour that also finally generates economic consequences. The fast developments within the financial sector also stimulate the global character financial reporting, while the sophistication of some field in financial reporting, such as financial instruments, requires a corresponding response through accounting information and its disclosure.

Our project aims the implementation of the model being developed through the perspective of governance practices. Accounting and financial information is necessary for the functioning of the financial system. Moreover, the clarification of some accounting fundaments is required through the perspective of social responsibility and sustainable development that characterize the capitalist system. If we are to add to the theories discussing the disclosure information that we pointed within the literature review part of the paper, the legitimacy theory and the theory of interested parties should be mentioned.

\section{Acknowledgements}

This work was supported by CNMP, project number 92-085/2008. The project is entitled "Developing a functional model for optimizing the national strategy regarding financial reporting 
within Romanian private sector entities".

\section{References}

1. Alexander, D., Jermakowicz, E., 2006. A True and Fair View of the Principles/Rules Debate. Abacus 42(2), pp. 132 - 164

2. Bhimani, A., 2008. The role of a crisis in reshaping the role of accounting. Journal of Accounting and Public Policy 27, pp. 444-454

3. Bonaci Carmen Giorgiana, Matiş Dumitru, Mustaţă Răzvan V., 2010. Framework for Documenting National Accounting Practices' Orientation Towards IAS/IFRS. Journal of International Management Studies, 10(3), pp. 125-132

4. Bonaci Carmen Giorgiana, Jiri Strouhal, Dumitru Matiş, 2010. Current Debates on Accounting for Financial Instruments: Perspectives in the Aftermath of a Crisis. Journal of International Management Studies, 10(2), pp. $19-27$

5. Carmona, S., Trombetta, M., 2008. On the global acceptance of IAS/IFRS accounting standards: The logic and implications of the principles-based system. Journal of Accounting and Public Policy 27, pp. 455-461

6. Choi, F. D, 1973. Financial disclosure and entry to the European capital market. Journal of accounting research $11(2)$

7. Davis, S., Meyer, C., 1998. Blur: The Speed of Change in the Connected Economy, Addison-Wesley

8. Hughes, P. J., 1986. Signalling by direct disclosure under asymmetric information. Journal of accounting and economics 8(2)

9. Jensen, M., Meckling, W., 1976. Theory of the firm: managerial behaviour, agency costs and ownership structure. Journal of Financial Economics 3

10. Nelson, M.W., 2003. Behavioural evidence on the effects of principles- and rules-based standards (commentary). Accounting Horizons 17, pp. 91-104

11. Nobes, C., W., 2005. Rules-Based Standards and the Lack of Principles in Accounting. Accounting Horizons 19(1), pp. 25.34

12. Pitt, H. L., 2002. Oral Testimony Concerning Accounting and Investor Protection Issues Raised by Enron and Other Public Companies Before the Senate Committee on Banking. Housing and Urban Affairs, 21 March 2002

13. Rérolle, J.-F., 1998. Value creation in the connected economy. Analyse financière, available at http://www.rerolle.eu/public/1998f_Value_Creation_in_the_Connected_Economy_Traducti on_Analyse_financi_re_oct_1998.pdf, accessed at 19.05.2009

14. Rérolle, J.-F., 2008. The fair value debate: from accounting utopia to financial realism. Revue Trimestrielle de Droit Financier4, pp. 1-12

15. Schipper, K., 2003. Principles-based accounting standards. Accounting horizons 17(1), pp. 61-72

16. Watts, R. L., 1977. Corporate financial statements, a product of the market and political processes. Australian Journal of Management 2

17. Watts, R. L., Zimmerman, J. L., 1986. Positive accounting theory, Prentice-Hall, Englewood Cliffs, NJ. 